of the advance are represented by a curve or curves which would require a series of careful experiments to be carried out in each instrument, followed by difficult and elaborate calculation for each advance.

Much credit is due to the author for working out the modifications, but until we have some original method of finding a steady-point, not so far suggested, it is doubtful if we can improve on the Gray, Ewing, and Milne seismographs, that are not, as the author imagines, little used or tested instruments.

H. J. JOHNSTON-LAVIS.

\section{PHYSICAL GEOGRAPHY AND CLIMATE OF NEW SOUTH WALES.}

A SECOND edition of an excellent pamphlet on the "Physical Geography and Climate of New South Wales," by Mr. H. C. Russell, F.R.S., astronomer royal for New South Wales, has just been issued at Sydney. It is published by authority of the New South Wales Government. The following extracts may be of interest to various classes of readers in Great Britain :-

Looking back through the pages of history, and the dim traditions of an earlier time, we find abundant evidence of a belief in the existence of a great south land to the south and east of what was tben the well known earth. Those early navigators whose travels had fostered this belief, had doubtless followed down the Malay Peninsula and the string of islands which seem to form part of it, in search of spices and other treasures which the islands supplied. Pliny, who had evidently gathered up the traditions of "Terra Australis incognita," says that it lay a long way south of the Equator, and in proof of this mentions the fact, strange in those days, that when some of its inhabitants were brought to civilization they were astonished to find the sun rise on their left hand instead of on their right. And Ptolemy, A.D. I 70 , after describing the Malay Peninsula, says: Beyond it, to the south-east, there was a great bay in which was found the most distant point of the earth ; it is called "Cattigara," and is in latitude $82_{2}^{\circ}$ south ; "thence (he goes on to say) the land turns to the west, and extends an immense distance until (as he believed) it joins Africa." And it may fairly be assumed that the extreme south latitude of Cattigara, and its situation in a great bay where the land turns to the west until it joins Africa, is proof that it was some point in the Gulf of Carpentaria, for no other place would fulfil the conditions. The idea that the land actually reached Africa was not Ptolemy's ; it was a necessary part of the system of Hipparchus, for he taught that the earth surrounded the water and prevented it from flowing away. It is not surprising, therefore, that the early navigators, following down the islands, came at length to that part of the Gulf of Carpentaria where the land turned to the west; and believing Hipparchus' system of geography, thought that in turning to the west they were in reality turning towards home, and Cattigara was therefore the most distant point known. Marco Polo tells us that the Chinese navigators in his day (A.D, I293) asserted there were thousands of islands in the sea to south of them, and in the present day we find proofs of their early visits to Australia in the traces of Chinese features amongst the natives of the northern coast ; indeed, some historians think that Marco Polo, in the account he gives of the expedition sent to Persia by the Great Khan, refers directly to A ustralia, under the name of Lochac. This place he says was too far away to be subjugated by the Great Khan, and was seldom visited; but it yielded gold in surprising quantity, and amongst other wonders contained within it an immense lake or inland sea. It is im possible that such a description should apply, as has been thought, to the Malay Peninsula, - a country within easy reach, and one which his ships must have passed in every voyage; and so far from being beyond his power, it was within the limits over which his sway extended. That Lochac formed part of the main-land was also quite in accordance with their ideas of the earth, which surrounded the ocean, and the abundance of gold is certainly more likely to be true of Australia than of the Malay Peninsula.

For long years after Marco Polo we find no direct reference to Australia, except the stories which lived amongst navigators, and seemed to lose none of their marvellous points by transmission. These kept alive the desire to explore the great south land, so rich in treasures and wonders. All the evidence collected so far goes to prove that the Portuguese had, early in the sixleenth century, explored at least the northern parts of Australia What they learned was, however, kept a profound secret until about 1540 , when one of their government maps was stolen; and there are now in existence six maps believed to be copies of it, which were all published betw een 1539 and 1555 . These all show Australia under the name of the "Land of Java," the real Java being called the "Little Java," and from this time onward frequent attempts were made to explore what had for so many generations been "Terra Australis incognita." Sturdy navigators could not understand the silence of the Portuguese, except as proof of the richness of the land, about which tradition told wonderful tales. "It was a land of gold and spices, of magnificent tropical fruits and vegetation-a perfect paradise, in which the happy and simple inhabitants were Joaded with jingling ornaments of gold. Its very atmosphere was elixir, and existence a round of enjoyment." No wonder that in an age when, at least upon the ocean, the power to take was mistaken for the right to do so, there were many who cast longing glances towards the southern Paradise. Whether these stories of gold had any foundation in fact or not, when barter was regularly exchanged on the coast of Australia, it is impossible now to say, but more recent discoveries of rich surface gold lend some colour to them, and the vegetable richness of the northern part of Australia is quite in accordance with tradition. But all the early English navigators were unfortunate, and Australia got a reputation the very reverse of what further investigation has shown that it deserves. In point of fact, all the glowing colouring of tradition is true; but when Dampier, in 1688, sailed down the western coast, he saw nothing but a " dry sandy soil," and the "miserablest people in the world"; and later on, when the first English settlers landed on Australia, they chose a bay, beautiful to look at, but there was no gold and no fruit worthy of the name, the soil was barren and sandy, and the climate in the worst part of its summer. No wonder that the fame of Australia was black. ened, and report made it a miserable land, subject to droughts and floods-a land in which everything was turned topsy-turvy. The summer came at winter time; trees shed their bark, not their leaves-were brown instead of green; the stones were on the outside of the cherries; and the pears, pleasant to look at, were only to be cut with an axe: and there was nothing to eat, " unless, perchance, ye"l fill ye with root of fern or stalk of lily." Such was the early verdict upon Australia. Fortunately the first colonists, once here, were obliged to stop. By degrees they found that everything that was planted grew well; that wheat in the valley of the Hawkesbury yielded 40 to 50 bushels to the acre, and in one memorable season actually ruined the farmers by its very abundance, for in the then limited market, the price fell so low that it was not worth gathering, and it was left in the fields to rot, while the farmers sought other work. Horses, sheep, cattle, and pigs hrove marvellously, and some of the cows getting away, the bush soon contained numbers of wild cattle. Even wool did not deteriorate in the new Colony; and step by step the facts became too strong for prejudice, and the first fleeces of Australian sheep sent to England lifted the veil. Manufacturers would gladly take as many as could be sent; their demand for more wool extends with the supply, and now only from Australia can they obtain the fine wools which they need. Quantity and quality of wool have increased together, and the Grand Prize at the Paris Exhibition for our New South Wales wool has proclaimed the fact far and wide. Wool has done still more for the Colony. We took possession of it as a narrow strip of coast country; the demand for pasture forced us to find a way over a hitherto impassable range, and the same want has driven all the desert out of the Colony, and covered it with sixty-two millions of valuable sheep (1892). The country which early writers upon Australia called a barren waterless desert is now growing the finest wool and yielding abundant water from wells, and when, in 1851 , it was announced that gold had been discovered in abundance, the world was convinced that Australia was a promising country after all. Year by year the people have been coming in increasing numbers to supply our great want (population), and as our numbers increase new avenues of wealth and prosperity are opening before us.

Geographically, Australia has a grand position, lying between the Ioth and 4oth degrees of south latitude-that happy mean where it is neither too hot nor too cold. Surrounded by the ocean, the sea breezes temper what might otherwise be a hot climate in the sunmer; the air is clear and dry, and yet brings rain in heavy showers. Vegetation is abundant, and includes

NO. I 2 I I, VOL. 47] 
all the cereals and fruits of the world, so that, in the words of the old tradition, it has "all the conditions which make life a pleasure."

Australia measures from north to south r 900 miles, and from east to west 2400 miles, and speaking generally, has a rounded outline, the only great inlets on the coast-line being the Gulf of Carpentaria and the Australian Bight. The total area is rather greater than that of the United States, and almost equal to the whole of Europe. On the east, north, and west, and at a short distance from the coast are found ranges of mountains, of no great elevation, yet almost the only high land. On the west and north-west coasts the mountains form a bold outline of granite, rarely more than 200 miles from the coast, and attaining to heights of 2000 to 3000 feet. Between these and the sea the land is low and grod, but on the inland side is found a vast table land which slopes towards the unknown interior so gradually that the inclination is not easily seen, and no rivers running to the interior have yet been discovered-all known streams running to the sea.

On the east coast we have also the mountain chain parallel to the coast, but it is much higher and more extensive, and the strip of low land by the coast is much narrower, often not more than 30 miles wide, and at Point Danger the range comes right to the sea. This grand chain of mountains is known generally as the Great Dividing Range, and extends for about 1500 miles along the east coast. Near its southern extremity is the Snowy Range, the only spot in Australia where snow may always be found. The highest peak, Mount Kosciusko, 7170 feet, is also the highest land in Australia. The ravines on its sides always contain snow, and the mountains near it, about 6000 feet high, are also covered with snow for the greater part of the year.

Of this great continent island, the Colony of New South Wales holds the choicest portion-the southern part of the east coast-the part where, with remarkable sagacity, the first settlement was made. It has the best climate, all the most important rivers in Australia, the great bulk of the coal land, unlimited stores of all the useful minerals, and the finest pastoral and agricultural lands for extra-tropical vegetation; besides which, its extensive highlands afford climatic conditions for all purposes. It is naturally divided into three portions. The comparatively narrow coast district, from 30 to 150 miles wide, abundantly watered by rivers and smaller streams coming down from the mountains. The rainfall here, fed by winds from the Great Pacific Ocean, is very abundant, from 40 inches in the south to 70 in the north, and at Sydney 50 inches. The moun. tains have doubtless very much to do with this abundant precipitation, and at times the rains are so heavy that the rivers, fed by mountain torrents, carry heavy and dangerous floods. In years past wheat was largely and profitably grown, but rust has of late so frequently appeared that little or no wheat is grown, for it pays better to supply the city markets with dairy produce, Indian corn, and various kinds of hay. In the northern districts sugar-growing is a profitable industry, and increasing rapidly. About Sydney enormous quantities of oranges are grown for exportation.

The second division includes the mountains and elevated plains, and extends the whole length of the colony, varying in width from 120 to 200 miles. On the south, with the exception of the Monaro Tableland, the country is very rough and mountainous, the highest points, Mount Kosciusko and the Snowy Range, catch the rain and snow that feed the river Murray and the Murrumbidgee. Wheat grows well here, but nearly all the land is used for pastoral purposes. Proceeding northwards, the mountains decrease in height and extend laterally. A part of the land is taken up for agriculture, some for mining. In its natural state the western country is open plain or lightly-timbered, and large areas are covered with rich volcanic soil which seems fit to grow anything, but the want of labour and carriage, and the profit and security to be found in raising wool and meat, has for the most part tempted capital into squatting pursuits; but since the railway has reached this part of the country more attention is being given to agriculture, and it is rapidly extending. Between Goulburn and Bathurst, the western waters form the Lachlan and the eastern the Hawkesbury rivers, and from Bathurst northwards to latitude $25^{\circ}$ all the western waters go to form the various tributaries of the Darling river. These mountains are from 2000 to 3000 feet, with some peaks rising to nearly 6000 feet. The central parts of the western slopes are celebrated for rich soil and herbage, and here also the greater part of the gold-mining area, as well as mines for other minerals have been found, including coal, which is also found in great abundance, with iron and lime, at Lithgow and other places. Deposits of copper, silver, lead, tin, and mercury are also found in abundance. A very large portion of the high land here is suitable for agriculture, and is being taken up for that purpose by degrees. English fruits-the apple, cherry, currant, \&c. - grow to perfection here, as well as in other parts of the mountain districts.

The third division covers by far the greatest area, and consists of the Great Western Plains, extending away to the Darling river, and thence to the south Australian border. Here there are but few known mineral deposits except copper, and the enormous deposits of silver and lead at Broken Hill, and no attempt at agriculture. All the land may be said to be held for grazing purposes, and for that purpose, now that capital has been invested in tanks and wells for water supply, this country is unequalled. Sheep and cattle thrive in a remarkable degree, and form a most profitable investment, the climate being dry and wonderfully healthy for man and beast.

These are the three great natural divisions, made so by the conformation of the land and the climate. It will be evident from what has been said of the elevation of the mountains that snow is not a common feature upon them, and the only part where snow lies for any considerable time is the extreme south. As a necessary consequence, the river system is peculiar; indeed, it has often been asserted that Australia had no rivers at least none which were of any use as such; but as we shall presently see, this statement, like many others affecting Australia, was made in ignorance. The necessity for increased pasture had driven the early colonists to cross the Great Dividing Range, aptly so-named, in search of pasture, in 1815 , and the desire to extend the new pastures beyond the Bathurst Plains, which were the first discovered, led them on, and one of the first questions that demanded their attention was to account for the direction in which all the streams were flowing. The shortest road to the sea was to south-west, and yet all the water was running to north-west, and quite naturally it was asked-Could there be a great inland sea into which these rivers discharged? In 1818 Oxley started with a determination to see where at least one of them went to ; so he followed the Macquarie for more than $200 \mathrm{miles}$, and found that he was going due north-west, further and further, as it seemed to him, from the natural outlet on the south coast. At last the river spread out to an apparently interminable marsh. Turn which way he would his progress was stopped by a shallow freshwater sea, for sea he was at last convinced it must be, so great was its extent, and he was obliged to turn back. He had got there after two very wet seasons (1817 and 1818 ), and his inland sea is now known as the Macquarie Marshes; and the mystery was not solved until Sturt, in 1829 , found all these streams trending to north-west unite in the Darling, and then turn to south-west.

Coming from mountains of such moderate elevation, these streams are necessarily dependent upon the rainfall, and have no snow to help them, so that in rainy seasons they become important rivers and in dry ones sink into insignificance; but since most of the rains which feed these waters are, as it were, offshoots of the tropical rains, they seldom fail altogether, and as a rule the Darling is navigable for four months of each year, and sometimes all through the year, up to and beyond Bourke. The current is very slow, seldom reaching two miles per hour, and therefore offers little hindrance to the steamers which carry wool and stores.

In the exploration of our rivers there was another surprise when settlement extended south-west from Sydney. The waters here were found to flow to the west, and the Lachlan has for a considerable portion of its course a south-west direction, that is, at right-angles to the Macquarie and the Bogan. Could the Lachlan, the Murrambidgee, and the snow-fed Murray ultimately join the waters that ran north-west from Bathurst? Sturt had not solved this question-he only followed the Darling part of the way down-and it was left for Sir Thomas Mitchell to find the junction of the two river systems in 1835 , and to prove that the Darling and the Murray were united at and below Wentworth.

After dealing with the rivers and harbours of New South Wales, Mr. Russell discusses the temperature, rainfall, droughts, and winds of the colony. Of the temperature he says :-

NO. I 2 I I, VOL. 47$]$ 
In works of reference, Australia generally is credited with heat in excess of that due to its latitude. It is difficult to say why, unless it arose from a habit of one of our early explorers who carried a thermometer and carefully published all the high, and none of the low readings he got, until, fortunately for the colony, the thermometer was broken and the unfair register stopped. But not only the interio--Sydney even to the present day is credited, in standard works of reference, with a mean temperature of $66.2^{\circ}$, or more than three degrees higher than the true mean, which is $62.9^{\circ}$. Such an error is not excusable when meteorological observations have been taken and published for just torty years. There is another error made by some writers when describing Australia. It is shown by them inverted on the corresponding latitudes in Europe, and the reader naturally infers that Australia is as hot as those parts of Europe. Confining our attention to New South Wales, that is between $29^{\circ}$ and $37^{\circ}$ of south latitude, we find that generally it is cooler than a corresponding part of Europe. The mean temperature of the southern parts of England is about $52^{\circ}$, and that of France, near Paris, about the same, in creasing as you go south to $58.5^{\circ}$ at Marseilles. Taking this as a sample of the best part of Europe, let us see how the mean temperatures in the colony compare with those: Kiandra, our coldest lownship, situated on a mountain, is $46^{\circ}$; Cooma, on the high land, $54^{\circ}$; Queanbeyan, high land, $58^{\circ}$; Goulburn, high land, $56^{\circ}$; Armidale and New England district, $56^{\circ}$; Moss Vale, $56^{\circ}$; Kurrajong, $53^{\circ}$; Orange, $55^{\circ}$. These towns are scattered along the high table-lands from south to north, and represent fairly the climate of a very considerable portion of the whole colony. Next to this in point of temperature is the strip of land between the ocean and the mountains, and which is affected by the cooling sea-breezes. Here we have a mean temperature ranging from $60^{\circ}$ at Eden, the most southern port, to $68^{\circ}$ at Grafton, one of the northern ports. Sydney, in latitude $34^{\circ}$, has a summer temperature only four degrees warmer than Paris, which is in latitude $49^{\circ}$. Now the usual difference for a degree in latitude is a degree in temperature, and therefore, if Sydney were as much warmer than Paris as its latitude alone would lead us to expect, its temperature should be $74^{\circ}$, and that is $15^{\circ}$ warmer than Paris ; but as we have seen, it is only $4^{\circ}$ warmer. This single example is enough to prove the comparative coolness of our coast districts. The in. vestigation made during recent years shows that the mean temperature of the whole colony, as derived from forty-five stations scattered over it, is $59^{\circ} 5^{\circ}$, three degrees lower than that of Sydney, or only one degree hotter than that of Paris.

It may be mentioned that the highest shade temperature ever recorded in Sydney was $106.9^{\circ}$, and near Paris a temperature of $106.5^{\circ}$ has been recorded.

The third great district, consisting of lower land and plains to the west of the mountains, bas a climate considerably warmer in summer than the parts above described, owing to the powerful effect of the sun on land having little forest and little or no wind; but in winter the temperature sinks down much lower than the coast districts, owing to the great radiation; so that the annual mean temperature is not so great as the summer heats would lead one to anticipate. A table has been prepared for the purpose of showing by comparison with many places in Europe and America the temperature of the colony. The places have been arranged in order of temperature, taking for that purpose the mean annual temperature. This shows at once that the range of temperature here is equivalent to that offered by Europe from the north of England through France to Sicily. Such a range is more remarkable, because if New South Wales were placed on the map of Europe according to its latitude it would extend from Sicily to Cairo, whereas when placed by its temperature it stretches as we have seen from Sicily northwards to England. Nor is this all that the table shows us. For even when we find a place in Europe with a temperature equal to that of some place here, it is at once observed that the summer temperature in Europe is warmer than the colonial one and the winter colder; for instance, Naples, $60.3^{\circ}$; Eden, $60.3^{\circ}$, summer at Naples, $74^{\circ} 4^{\circ}$; at Eden, $679^{\circ}$; winter at Naples, $47^{\circ} 6^{\circ}$; Eden, $5^{\circ}{ }^{\circ}$; and so generally the southern country has the cooler and more uniform temperature. It is worthy of remark that the only places here of equal mean and summer temperature with places in Europe are those which are to be found on the western plains, as at Wagga Wagga, which has a mean temperature of $60^{\circ} 3^{\circ}$; Naples, $603^{\circ}$; and summer temperature of both is $74^{\circ}$; or again, to compare the places of the same or nearly the same latitude, Messina, in Sicily, latitude $38^{\circ} \mathrm{I1}^{\prime}$, has a mean temperature of $66^{\circ}$, summer $72^{\circ} 2^{\circ}$, winter $55^{\circ}$; Eden, New South Wales, in latitude $37^{\circ}$, has a mean temperature of $60^{\circ} 3^{\circ}$, summer $67^{\circ} 9^{\circ}$, winter $5^{\circ} 9^{\circ}$; or Cairo, in latitude $30^{\circ}$, mean of $72^{\circ}$, summer $85^{\circ} 1^{\circ}$, winter $58.2^{\circ}$; Grafton, latitude $29^{\circ} 45^{\prime}$, mean $68^{\circ} 1^{\circ}$, summer $768^{\circ}$, winter $584^{\circ}$. It is useless to multiply examples,-we have here enough to show how much cooler Australia really is than the fervid imaginations of some writers have made it appear in print.

Looking at this question of temperature generally, it will be seen that New South Wales is no exception to the general deduction of science that the southern lands are cooler than thuse of corresponding latitudes in the north, and it is only during hot winds, which are very rare in New South Wales, that the temperature rises to extremes. But to leave Europe, and compare the climate of New South Wales with that of America. Our limits of latitude would place us from Washington to New Orleans. Now the mean temperature at Washington is $55^{\circ}$ and at New Orleans $68^{\circ}$, while that of Eden is $60^{\prime} 3^{\circ}$ and Grafton $68.1^{\circ}$; so that if mean temperature were a complete test of climate it would appear that our const is hotter than corresponding latitudes in America. But mean temperature is not enough ; we must compare the summer and winter temperatures; and summer at Washington rises to $76.7^{\circ}$ and at Eden only to $67.9^{\circ}, 9^{\circ}$ cooler; New Orleans summer is $82^{\circ}$ and Grafton $76^{\circ} 8^{\circ}$; but $82^{\circ}$ hardly represents the summer heat at New Orleans, for it is a steady broil, during which every day for three months of summer the heat is over $80^{\circ}$, a temperature that is only reached on this coast during hot winds, or in other words, very seldom. But winter temperature at Washington falls to $37^{\circ} 8^{\circ}$, and at New Orleans to $56^{\circ}$; at Eden $519^{\circ}$, and at Grafton $584^{\circ}$. Hence it is evident that on this coast the heat is very much less in summer and greater in winter than upon the coast of America. Such facts place the colony in a very different position in regard to climate from that which it has occupied in published works, for instead of being a hot country we see that its coast districts are much cooler than corresponding latitudes in Europe and America, and that in its elevated districts, which comprise a large part of it and much of the best land, it has a climate no warmer than the best and most enjoyable parts of Europe in much higher latitudes; but while bringing these facts into due prominence it is not the intention to deny that another considerable part of the colony, forming the western plains, is subject to greater heat, caused, no doubt, by the sun's great power on treeless plains, and the almost total absence of cooling winds; yet, although in summer the temperature here frequently rises over $100^{\circ}$, and sometimes up to $120^{\circ}$, yet, owing to the cold at night and in winter, the mean temperatures are not greater than those of corresponding latitudes in the northern hemisphere; and this part of the colony being remarkably dry, the great heat is by no means so enervating as a temperature of $80^{\circ}$ in the moist atmo-phere of the coast, and, what is of still more importance, it does not produce those terrible diseases which are usually the offspring of hot countries. This is also, no doubt, due to the dryness of the air. Stock of all kinds thrive remarkably well, and are very free from disease in those hot western districts.

\section{SCIENTIFIC SERIALS.}

THE Quarterly Journal of Microscopicul Science for August I892 contains:- On the anatomy of Pentastomum teretiusculum (Baird), by Prof. W. Baldwin Spencer, M. A. (Plates i. to ix.). Whilst collecting on Kings Island, which lies to the west of Bass Straits, half-way between the mainland of Victoria and Tasmania, numerous specimens of the copper-head snake (Hoplocephalus superbus) were found, in the lungs of which a large species of Pentastomum were parasitic; afterwards the same parasite was discovered in the lungs of the black snake (Pseudechys porphyriacus) in Victoria; on examination there seemed little doubt but that the species was the one described by Baird long ago (1862) from specimens obtained in the mouth of a dead copper-head snake in the Zoological Gardens, London, under the name of Pent. teretiusculum. In this paper we have a very complete account of the anatomy of this form, there being descriptions and figures of its external anatomy, schematic

No. I 2 I I, voL. 47] 